\title{
LABUH LABET: \\ PENGABDIAN PRAJURIT KERATON YOGYAKARTA \\ DALAM KARYA TARI
}

\author{
Putra Jalu Pamungkas \\ Pascasarjana Institut Seni Indonesia Yogyakarta \\ Email: putrajalupamungkas@gmail.com
}

\begin{abstract}
ABSTRAK
Labuh labet memiliki makna pengabdian. Di dalam karya tari ini, pengabdian yang dimaksud adalah pengabdian seorang prajurit kraton Yogyakarta atau yang dikenal dengan Bregada. Bregada prajurit kraton biasanya disajikan pada upacara-upacara adat di kraton. Banyak para prajurit kraton yang sudah berusia lanjut namun masih tetap memiliki semangat untuk ikut berpartisipasi dalam acara kraton. Dasiyo (77 tahun) sebagai salah satu contohnya, beliau adalah seorang prajurit kraton yang mengalami awal dibentuknya kembali prajurit kraton Yogyakarta. Beliau pernah masuk di tiga bregada prajurit kraton yang berbeda yaitu prajurit Dhaeng, Patangpuluh, dan Wirabraja dengan pangkat yang berbeda-beda. Bregada prajurit kraton Yogyakarta sebagai inspirasi penciptaan karya tari, berawal dari ketertarikan saat melihat barisan prajurit kraton Yogyakarta. Dalam setiap kesatuan masing masing bregada memiliki ciri khusus yang berbeda, baik dalam segi kostum, gerakan dan musik. Ada sebuah motif gerak berjalan yang dilakukan oleh setiap bregada prajurit yaitu lampah macak dan lampah mars. Prajurit identik dengan pengabdian, kedisiplinan, dan kesetiaan. Sifat dan karakter dari prajurit ini dijadikan spirit dalam pengolahan dan pengekspresian setiap motif gerak yang ditemukan. Karya tari ini merupakan koreografi garap kelompok dengan delapan orang penari laki-laki. Enam penari sebagai visualisasi figur tokoh prajurit kraton, satu orang penari sebagai visualisasi masa lalu dari tokoh prajurit tersebut, satu penari lagi sebagai visualisasi figur pak Dasiyo. Lampah macak dan lampah mars menjadi motif awal untuk menciptakan gerak, dengan beberapa variasi dan pengembangannya. Melalui karya ini diharapkan generasi-generasi muda dapat melestarikan sejarah dan tradisi kebudayaan yang ada di wilayah masing-masing.
\end{abstract}

Kata kunci: prajurit, Bregada, keraton Yogyakarta 


\begin{abstract}
Terms or word as titles, has the same meaning as dedication. In this dance work, the purpose of dedication is soldiers of the Yogyakarta palace dedication. The soldiers of Yogyakarta palace usually served in the palace ceremony. A lot of older people soldiers of the palace however still have a spirit for participation in the palace event. Dasiyo (77 years old) as one of example, he is soldier of Yogyakarta palace to have experience ever since early reshaping soldiers of Yogyakarta palace. He ever in the three of different soldier of palace which name is Dhaeng, Patangpuluh and Wirabraja with different grade. The soldiers of Yogyakarta palace as inspiration for create this dance work, starting from the interest when looking the line up soldiers of Yogyakarta palace. In the every unity have different special feature, as a costume, movement and the music. Every soldiers have the one of walking movement motive that is lampah macak and lampah mars. The soldiers identic as dedication, discipline and loyalty. Human nature and character of this soldiers to be a spirit in processing and expression every found movement motive. This dance work is a group choreography with eight male dancer. Six dancer as a visualisation figure soldier of palace, one dancer as a visualisation past from soldier of palace, one dancer as a visualisation of Dasiyo. Lampah macak and lampah mars become early motive to create the movement, with the some of variation and development. Through this dance work expected young generation can preserve history and culture of tradition in the each other region.
\end{abstract}

Keywords: soldier, Bregada, Yogyakarta Court

\title{
I. PENDAHULUAN
}

Karya tari berjudul Labuh Labet merupakan koreografi kelompok yang mengekspresikan tentang pengabdian dan keteguhan hati seorang prajurit Kraton Yogyakarta. Prajurit yang dimaksud adalah bapak Dasiyo (77 Tahun), yang menjadi prajurit Dhaeng sejak bregada prajurit mulai dihidupkan kembali pada tahun 1969 hingga saat sekarang. (Wawancara Pak Dasiyo, 2017).

Prajurit sebagai pertahanan kraton diawali sejak masa pemerintahan HB I sampai pada masa pemerintahan HB VIII jumlah bregada prajurit terus dikurangi oleh para penjajah dengan tujuan ingin 'melemahkan' pertahanan kraton, hingga sampai sekarang ini memiliki sepuluh kesatuan bregada prajurit, di antaranya Wirabraja, Dhaeng, Mantrijero, Jagakarya, Patangpuluh, Ketanggung, Nyutra, Surakarsa, Bugis, dan Prawiratama. 
Pada tahun 60-an R.M Herjun Darpito memberi mandat kepada KRT Brojonegoro, Nitigurnito, R.M Tirun Marwito dan Prof. Dr. Y. Sumandyo Hadi, S.S.T., SU untuk merevitalisasi prajurit kraton Sejak saat itu bregada atau pasukan prajurit kraton dihadirkan kembali berada di bawah Penghageng Tepas Keprajuritan Kraton Kasultanan Yogyakarta (Wawancara dengan Prof. Dr. Sumandyo Hadi, S.ST., SU, 2017).

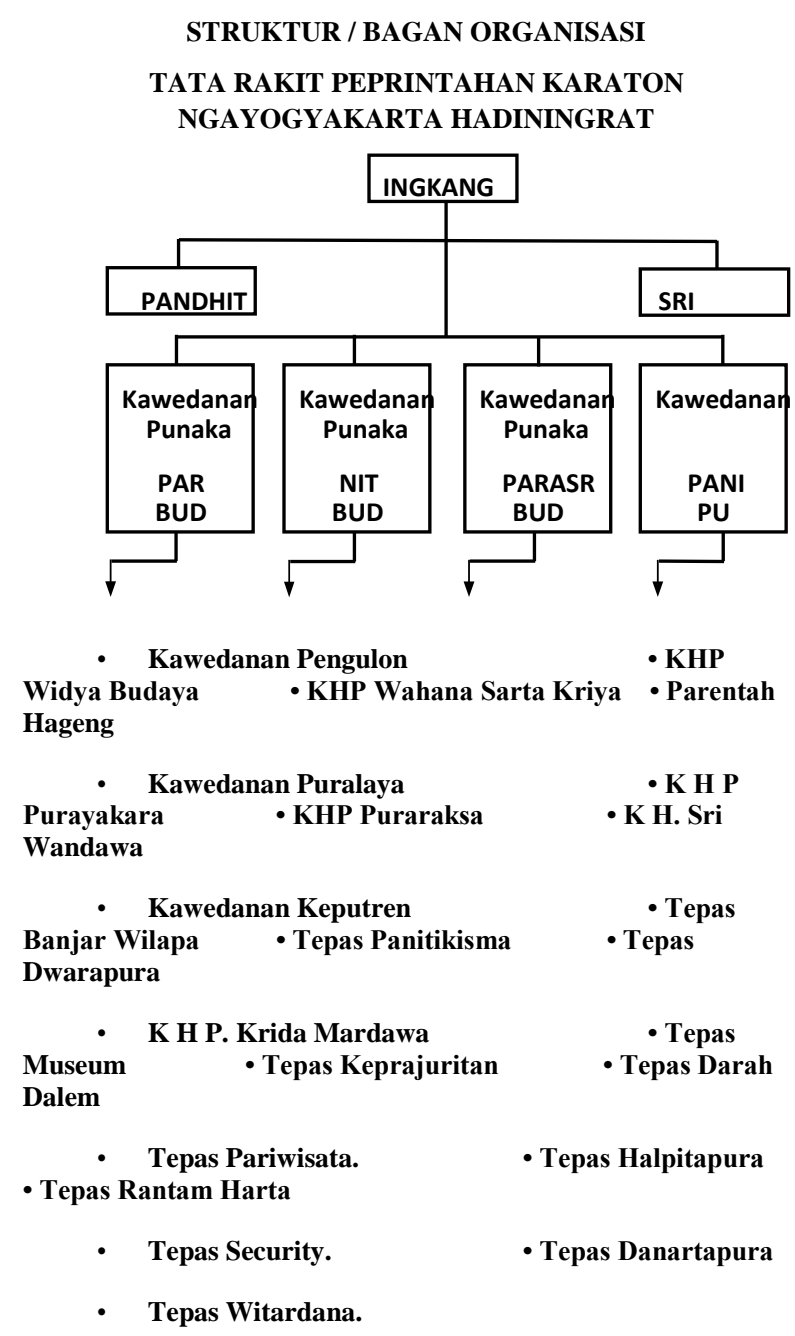

Gambar 1 : Struktur atau Bagan Organisasi Tata Rakit pemerintahan Kraton Yogyakarta. (bagan: Jalu, 2017 di Yogyakarta)
Lembaga ini didirikan pada tanggal 2 Maret 1971 (Wawancara dengan Enggar Pikantoyo, 2017) persetujuan Sultan Hamengku Buwono IX yang bertahta di kasultanan Yogyakarta sejak tahun 1940-1988 (Purwadi, 2007:525). Secara struktural tepas ini merupakan bagian dari kraton Yogyakarta. Saat ini Tepas Keprajuritan berada di bawah pimpinan KGPH Hadiwinata. Selain mengurusi keprajuritan, tepas ini juga mengelola Museum Pagelaran, Sitihinggil, dan Tamansari.

Setiap tahun bregada prajurit kraton selalu dilibatkan dalam upacara Grebeg. Upacara ini memiliki makna khusus yaitu upacara kerajaan yang diselenggarakan untuk memperingati hari kelahiran Nabi Muhammad SAW (Mulud) atau sekaten, merayakan Idul Fitri (Syawal), Idul Adha (Besar), serta acara-acara budaya khusus yang diselenggarakan kraton Yogyakarta (Purwadi, 2007:525).

Bregada prajurit kraton telah mengalami beberapa pergeseran tugas dan fungsi. Pada jaman dahulu prajurit kraton difungsikan sebagai prajurit perang, kemudian fungsi prajurit kraton Yogyakarta menjadi prajurit seremonial sampai sekarang ini. Dengan berbagai macam referensi mengenai prajurit kraton, penata mengambil spirit yang dimiliki oleh prajurit kraton Yogyakarta pada masa sekarang. Dari beberapa hasil wawancara dengan abdi dalem prajurit yang mengabdi di 
kraton Yogyakarta, ada beberapa alasan yang dikemukakan berkait pengabdian yang dilakukan di antaranya, mengabdi karena ingin nguri-uri kabudayan yaitu ikut andil dalam menjaga dan melestarikan kebudayaan Yogyakarta pada umumnya, dan keberadaan prajurit kraton Yogyakarta pada khususnya.

Karya tari ini mencoba untuk mengekspresikan laku atau gerakan para prajurit dalam kesatuannya sebagai bregada prajurit kraton. Di sisi lain, dalam penelitian selanjutnya, penata bertemu dengan seorang prajurit bernama pak Dasiyo. Beliau mengalami menjadi prajurit pada saat Bregada Dhaeng kembali dihidupkan pada tahun 1969, sampai akhirnya beliau naik pangkat dari yang semula menjadi Jajar menjadi Panji Dua dalam Bregada Patangpuluh dan menjadi Panji Parentah dalam Bregada Wirabraja. Prajurit yang berpangkat panji mayoritas seseorang keturunan dari kraton atau keluarga raja. Akan tetapi Dasiyo mendapatkan kesempatan untuk menyandang pangkat tersebut.

Dari perjalanan Dasiyo saat mengalami kenaikan pangkat, dapat dipetik satu nilai bahwa seorang Dasiyo menunjukkan totalitas pengabdiannya di kraton Yogyakarta. Dengan demikian dapat disimpulkan bahwa bregada prajurit kraton sebagai sumber menawarkan dua sudut pandang yaitu pengembangan gerakgerak prajurit dan spirit pengabdian Dasiyo, perjalanan beliau sebagai prajurit kraton dapat diterjemahkan ke dalam spirit karya sebagai penataan dan pemaknaan segmen-segmen karya.

\section{PEMBAHASAN}

\section{A. Konsep Koreografi}

Ide karya tari ini didapat saat melihat keunikan barisan prajurit kraton Yogyakarta, terutama pada gerakan prajurit yang disebut lampah macak dan lampah mars. Dasiyo sebagai salah satu prajurit yang dipilih sebagai narasumber mengatakan bahwa pilihan untuk menjadi prajurit tidak bisa dilakukan dengan setengah hati, tetapi harus dilakukan dengan sepenuh hati. Beliau diberi mandat menjadi Panji, tetapi beliau masih merasa belum pantas karena umumnya yang menjadi Panji berasal dari keturunan kraton sementara Dasiyo adalah warga biasa, karena itu adalah dhawuh dalem maka beliau bersedia menjadi Panji. Dari ungkapan itu termasuk juga penjelasan tentang bagaimana beliau menjadi Panji, maka disimpulkan bahwa Dasiyo menjalani pilihannya sebagai prajurit dengan sepenuh hati. Hal ini dapat dimaknai dengan labuh labet yaitu pengabdian yang mendalam. Pengalaman Dasiyo menginspirasi lahirnya koreografi kelompok dengan tema tentang semangat pengabdian. Penetapan rangsang tari seperti ini, Smith mengatakan sebagai rangsang gagasan (Ben Suharto, 1985:23). Selain rangsang 
LABUH LABET: PENGABDIAN PRAJURIT

KERATON YOGYAKARTA DALAM KARYA TARI

gagasan, penciptaan karya ini juga menggunakan rangsang kinestetik dan visual. Rangsang kinestetik berkaitan dengan ditetapkannya gerakan lampah macak dan lampah mars bregada prajurit sebagai gerak dasar untuk menemukan gerak-gerak berjalan yang lainnya, sementara properti yang digunakan oleh prajurit memberi motivasi untuk menggunakan properti yang hampir sama bentuknya dalam karya ini.

Tema yang muncul dalam karya tari ini adalah pengabdian atau labuh labet seorang prajurit kraton. Seorang prajurit mengabdi kepada kraton Yogyakarta tanpa mengharapkan imbalan apapun, ikhlas tanpa pamrih dan teguh dalam menjalankan kewajibannya. Kesungguhan dalam melaksanakan tugas dan kewajiban, keikhlasan dalam mengabdi dan keteguhan sikap dalam menjaga amanah yang diberikan, di antaranya dianalogikan dengan gerak-gerak seorang penari yang tenang di antara beberapa penari yang sedang melakukan gerakan jatuh bangun, jatuh dan selalu mencoba untuk bangkit kembali saat satu penari ditempa oleh beberapa penari lainnya.

Berkaitan dengan gagasan tentang konsep yang diambil mengenai pengabdian seorang prajurit maka penata menggunakan judul Labuh Labet. Labuh labet adalah jenis kata dalam bahasa Jawa yang dinamakan tembung saroja (dua kata yang memiliki makna yang sama atau
JOGED: Jurnal Seni Tari p-ISSN 1858-3989 | e-ISSN 2655-3171

hampir sama digunakan secara bersamaan) yang memiliki arti pengabdian.

Pengekspresian gagasan tentang semangat pengabdian seorang prajurit disampaikan dalam bentuk tari kelompok. Dalam pengolahan garap kelompok ini dihadirkan sosok penari tunggal yang berinteraksi dengan kelompok lainnya termasuk juga interaksi antar kelompok dalam kelompok yang besar. Meminjam istilah Smith bentuk ungkap ini dapat disebut sebagai tipe tari. Maka tarian ini dapat dikatakan memiliki tipe tari dramatik. Berkaitan dengan pemanfaatan gerak-gerak lampah macak dan lampah mars sebagai dasar untuk menemukan gerak-gerak untuk karya ini, maka karya ini bisa dikatakan memiliki tipe studi. Penyampaian gagasan tentang semangat pengabdian seorang prajurit tidak secara lugas. Artinya masih ada 'ruang' bagi penonton untuk menginterpretasikan dengan hal yang berbeda dari maksud koreografer. Pada beberapa bagian atau segmen dari struktur tarian ini disajikan gerak-gerak yang secara langsung dapat diidentifikasikan bahwa itu adalah sosok Dasiyo. Meminjam istilah Smith maka tarian ini dapat dikatakan memiliki mode penyajian atau cara ungkap simbolis dan representasional.

Gerak merupakan elemen dasar dalam sebuah koreografi. Pemilihan gerak dalam karya tari ini berdasarkan dari proses eksplorasi dan pengamatan terhadap gerak lampah macak dan lampah mars prajurit kraton. Pola gerak ini 
kemudian dikembangkan untuk menemukan variasinya. Hal ini mengacu pada pernyataan Smith yaitu 'lakukanlah sebuah motif itu sebagai sebuah benih', jika benih disiram dipupuk dan dibesarkan maka akan tumbuh tunas, cabang, daun, buah dan seterusnya. Motif awal yang sudah ditetapkan sebagai landasan atau dasar untuk menemukan motifmotif lainnya dicoba pengembangannya dari berbagai sisi yaitu ruang, waktu dan tenaga.

Pemilihan penari dilakukan dengan mempertimbangkan segi kesamaan postur dengan tubuh koreografer yang juga menjadi salah satu penari dalam karya ini. Selain itu, penari yang dipilih harus juga menguasai ketrampilan tari Jawa, karena dalam proses pencarian gerak menggunakan teknik dan polapola gerak dasar tari tradisi Jawa. Penata juga membutuhkan penari yang memiliki stamina yang tinggi untuk dapat merealisasikan kesamaan dalam gaya gerak, pertimbangan lainnya adalah salah satu penari yang sudah cukup lama berproses bersama dengan tujuan dapat membantu dalam mentransfer gerak ke penari.

Musik merupakan sebuah elemen pendukung untuk menambah roh dan suasana dalam karya tari. Untuk dapat menciptakan suasana daerah Yogyakarta dan roh prajurit kraton, maka digunakan gamelan Jawa dan instrumen senar drum sebagai alat untuk memainkan pola-pola gendhing sesuai kebutuhan karya. Musik disajikan secara live. Aba-aba menggunakan campuran bahasa Jawa dengan Belanda akan memotivasi adanya penggunaan vokal dalam karya.

Tata busana menggunakan elemen warna dan desain yang dimiliki oleh Bregada Dhaeng, Patangpuluh dan Wirabraja. Corak lurik biru yang digunakan bregada Patangpuluh akan dikombinasikan dengan warna putih pada busana Dhaeng dan warna merah pada busana Wirabraja. Bentuk kostum yang akan digunakan merupakan pengembangan dari surjan, iket atau blangkon dan menggunakan celana panji berwarna putih. Untuk memunculkan salah satu ciri bregada Dhaeng digunakan celana berwarna putih. Warna putih dominan digunakan oleh bregada Dhaeng untuk celana dan baju. Wajah penari dirias dengan tujuan untuk kebutuhan panggung. Tata rias digunakan untuk mempertajam dan mempertegas garis-garis wajah penari, hal ini berkaitan dengan konsep pemanggungan yaitu penonton berjarak dengan yang ditonton.

Panggung proscenium stage dipilih untuk tempat mempertunjukkan karya Labuh Labet. Hal ini dipertimbangkan berkaitan dengan pola lantai dan pengolahan formasi penari kelompok diarahkan hanya untuk dilihat dari satu sisi pandang. Gerakan penari juga menghasilkan suara yang akan menjadi musik dalam pertunjukan ini, Untuk itu pemilihan panggung prosenium stage yang bersifat indoor akan 
membantu keberhasilan suara yang diinginkan. Segmen introduksi dengan suasana tegang membutuhkan pencahayaan dengan redup tujuannya untuk memperlihatkan suasana gejolak pikiran Dasiyo pada saat diberi mandat oleh Gusti Yudha untuk menjadi Panji. Kosong dan gelap menjadi pilihan untuk memvisualisasikan kebingungan yang terjadi dalam pikiran. Cahaya yang redup juga dimunculkan dengan tujuan untuk memperlihatkan visual tersamar yang terjadi pada lingkungan Dasiyo saat mendapat dhawuh dalem, Dalam segmen pertama dan kedua membutuhkan pencahayaan wash light untuk memvisualisasikan suasana kraton Yogyakarta. Segmen ketiga membutuhkan pencahayaan dengan beberapa titik fokus untuk penguatan kemunculan beberapa penari dalam satu adegan.

Karya tari ini juga akan menghadirkan setting kain bermotif parang barong sebagai simbol kraton Yogyakarta. Kain ini ditempatkan di keenam side wing yang berada di prosenium stage, dengan panjang dan lebar hampir sama dengan ukuran sidewing yang ada. Penggunaan trap/level juga dibutuhkan untuk lebih memfokuskan objek tokoh Dasiyo saat muncul dalam adegan ending. Trap/level ukuran 2x1 ditumpuk menjadi dua tumpukan dan ditambah dengan trap ukuran $1 \mathrm{x} 1$ yang ditumpuk di atas dan di depannya sehingga membentuk anak tangga. Kain putih juga dihadirkan untuk dijadikan background yang berada di tengah-tengah di belakang backdrop dan dihadirkan buntal yang berada di depan kain putih, setting ini dihadirkan bersamaan dengan kemunculan sosok Dasiyo.

Karya tari Labuh Labet menggunakan iringan dengan format live. Penata tari beranggapan bahwa dengan live musik suasana dan emosi yang ingin disampaikan dalam karya tari ini lebih bisa dirasakan oleh penonton. Penata tari melakukan konsultasi dengan pembimbing II Gandung Djatmiko karena beliau lebih mengerti mengenai iringan dan perkembangan penata musik di daerah Yogyakarta ini. Setelah konsep dan ide gagasan dalam karya tari ini dijelaskan, beliau menyarankan tiga orang sebagai opsi yang memiliki kemampuan menciptakan iringan yang sesuai dengan konsep yang digunakan. Mas Sudaryanto, Mas Bayu Purnama dan Mas Muchlas Tabis Hidayat. Setelah itu penata tari mencoba menghubungi Mas Muchlas Tabis Hidayat, awalnya ia sedikit ragu karena sudah lama tidak membantu ujian S-1 ISI Yogyakarta. Setelah konsep, ide dan gagasan dijelaskan maka Mas Tabis bersedia membantu dalam menyelesaikan Tugas Akhir ini.

Tahapan selanjutnya yaitu menentukan pengrawit. Penata musik memilih pengrawit sesuai dengan kebutuhan yang ingin disampaikan dalam iringan karya tari ini. Karena isi dari karya ini menggunakan dasar 
pijakan gaya Yogyakarta dan prajurit kraton Yogyakarta, maka penata musik memilih pengrawit yang sudah biasa menabuh gamelan Yogyakarta, ada juga salah satu pengrawit yang dipilih merupakan anggota dari prajurit ungelungelan yang ada di kraton Yogyakarta. Hal seperti ini dilakukan untuk dapat mempermudah penata iringan untuk menciptakan iringan dalam karya tari ini.

\section{B. Wujud Koreografi}

1. Introduksi

Bagian introduksi dimulai dengan membuka frontcertain dengan visual kosong dan gelap di stage, sebagai wujud dari pikiran Dasiyo saat pertama kali diberi mandat oleh Gusti Yudha untuk naik pangkat menjadi Panji, beliau merasa bimbang sekaligus bangga, sebagai anak dari keluarga sederhana yang bukan merupakan keturunan kraton beliau ditunjuk menjadi Panji, saat itu seorang yang memiliki pangkat Panji hanya bisa dilakukan oleh keturunan kraton, tapi karena ini adalah kehendak dari panglima prajurit kraton atau sering disebut dengan Manggalayuda maka kejadian tersebut dapat terjadi. Di lain sisi dengan adanya kejadian seperti ini menyebabkan kecemburuan sosial antara dirinya dengan prajurit yang lain, saat mendapat pangkat menjadi Panji. Setelah itu muncul dua penari sebagai visualisasi Dasiyo dan gejolak hati beliau.
KERATON YOGYAKARTA DALAM KARYA TARI

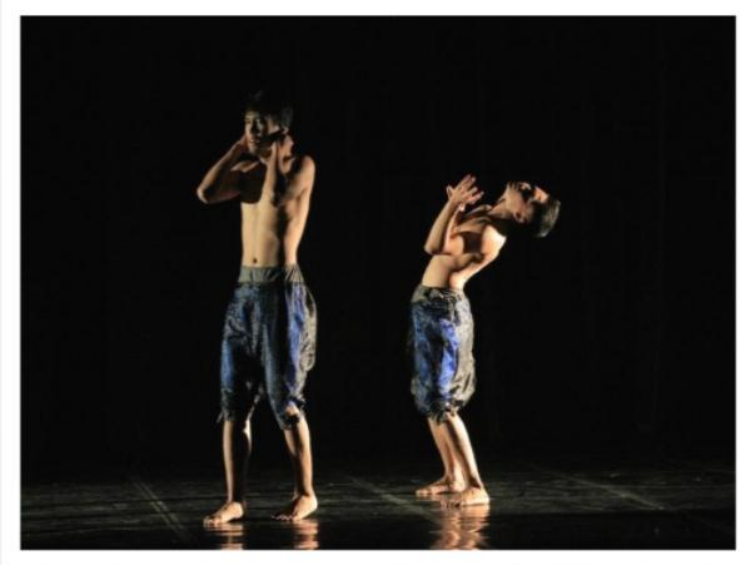

Gambar 2: Adegan introduksi visualisasi Dasiyo (depan) dan gejolak pikiran Dasiyo (belakang) (foto :

Joe, 2017 di stage jurusan tari ISI Yogyakarta)

Visual Dasiyo menunjukkan gerak dan simbol kebimbangan yang dirasakan pada saat itu, gejolak hati beliau divisualisasikan dengan teknik gerakan jatuh bangun. Setelah itu muncul beberapa penari sebagai visualisasi kecemburuan sosial yang berada di lingkungan Dasiyo.

\section{Adegan I}

Adegan satu memvisualisasikan tentang kebiasaan seorang abdi dalem yang berada di kraton Yogyakarta. Seorang abdi dalem identik dengan menggunakan busana jarik dengan wiron yang di engkol, baju peranakan dan iket atau blangkon. Busana ini divisualisasikan untuk dapat lebih menguatkan karakter dari seorang abdi dalem. Semua penari melakukan gerakan lampah ndhodhok, berjalan dan menyembah sebagai ciri khas seorang abdi dalem, hal ini ditunjukkan sebagai wujud dari 
pengabdian yang sangat tinggi terhadap kraton

Yogyakarta.

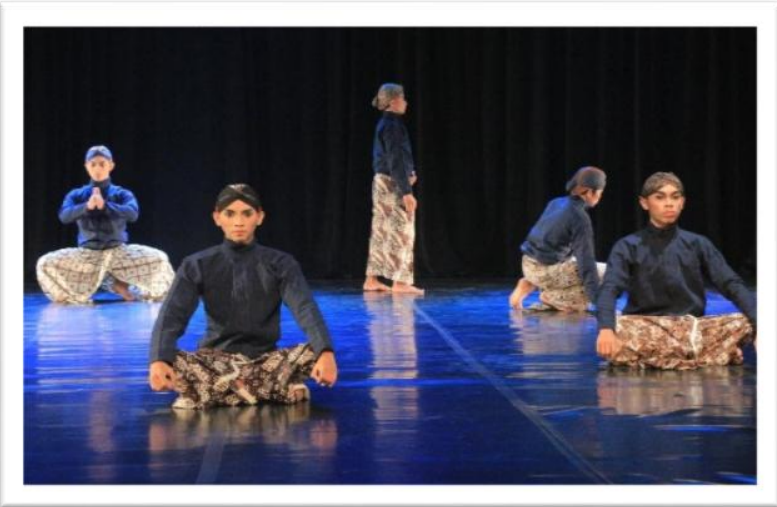

Gambar 3 : Adegan visualisasi abdi dalem kraton Yogyakarta. (foto : Joe, 2017 di stage jurusan tari ISI Yogyakarta)

\section{Adegan II}

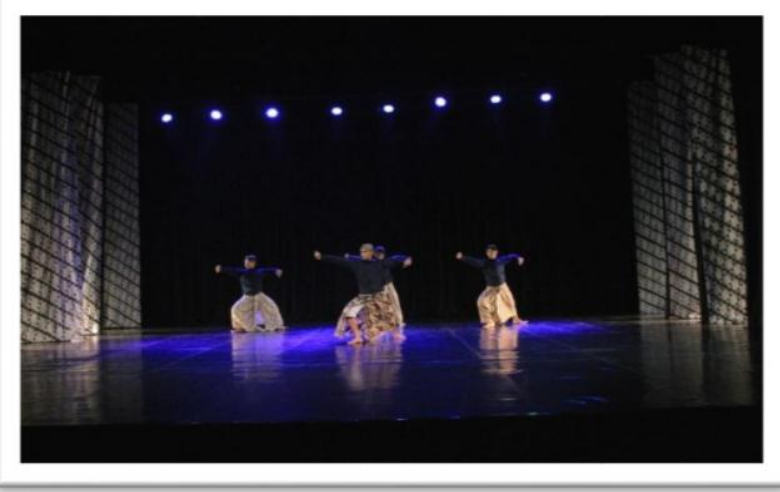

Gambar 4 : Adegan dalam melakukan motif tayungan dengan di latar belakangi oleh setting kain bermotif parang barong.

(foto : Joe, 2017 di stage jurusan tari ISI Yogyakarta)

Awal adegan dua memvisualisasikan pengembangan gerakan Bregada Nyutra pada saat melakukan lampah macak. Pengembangan baris berbaris dengan lebih menekankan pada gerakan kaki saat berjalan menjadi fokus dalam adegan ini.

\section{Adegan III}

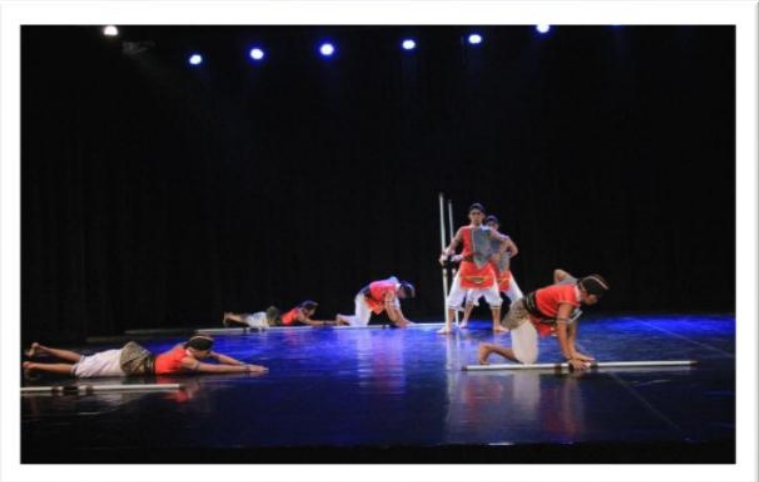

Gambar 5 : Adegan pengolahan tongkat dengan menggunakan busana keprajuritan.

(foto : Joe, 2017 di stage jurusan tari ISI Yogyakarta)

Adegan tiga lebih menekankan pada pengembangan properti tombak yang disimbolkan dengan tongkat. Pengolahan tongkat merupakan visualisasi dari ketangkasan seorang prajurit yang harus siap kapanpun dan dimanapun demi menjaga keamanan dan ketentraman kraton Yogyakarta. Hal ini juga dirasakan oleh Dasiyo, selama menjadi prajurit beliau selalu siap kapanpun dan dimanapun untuk melaksanakan kewajibanya saat mendapatkan dhawuh dalem atau mandat dari kraton.

\section{Ending}

Bagian ending menceritakan perjalaan dan perjuangan Dasiyo. Beliau mengaami beberapa gejolak hati saat menjadi prajurit, seperti merasakan kebimbangan saat diangkat menjadi Panji, harus senantiasa memiliki kesiapan jasmani dan rohani pada saat mendapatkan dhawuh dalem. Beberapa hal itu divisualisasikan oleh keenam orang penari, dan 
JOGED: Jurnal Seni Tari

p-ISSN 1858-3989 | e-ISSN 2655-3171

bersamaan dengan itu dimunculkan sosok Dasiyo ke dalam panggung dengan background semua penari tersebut

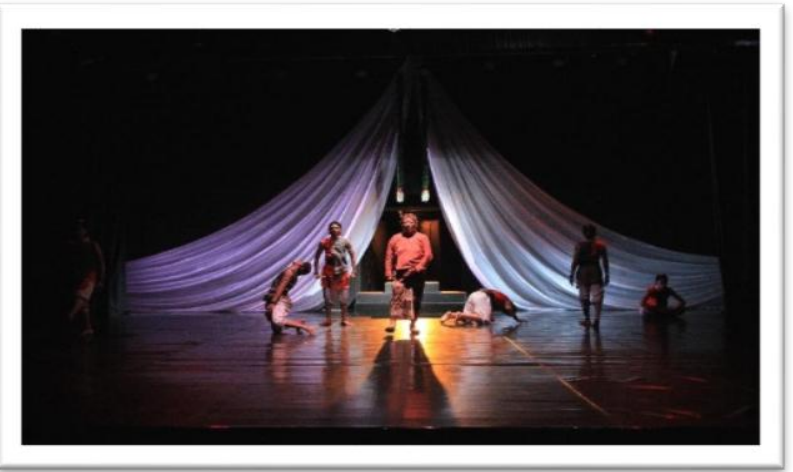

Gambar 6 : Adegan ending sebagai visualisasi pak Dasiyo dan perjuangan yang dilakukannya selama menjadi prajurit

(foto : Joe, 2017 di stage jurusan tari ISI Yogyakarta)

\section{PENUTUP}

Karya Tari "Labuh Labet" adalah sebuah karya tari ciptaan baru yang merupakan hasil penuangan ide serta kreativitas penata tari, yang dilatarbelakangi prajurit kraton Yogyakarta yang sudah menjadi kebanggaan budaya masyarakat Yogyakarta. Karya tari ini disajikan dalam bentuk koreografi kelompok, didukung tujuh penari putra dengan satu tokoh prajurit. Gamelan pengiringnya adalah beberapa instrumen Jawa berlaras pelog seperti demung, saron, bonang, gender, slenthem, kempul, gong dan dengan menggunakan instrumen kendang Jawa.

Dalam karya tari ini, dimunculkan spirit prajurit kraton Yogyakarta dengan visualisasi gerakan lampah macak dan lampah mars sebagai motif awal dalam menciptakan gerak
LABUH LABET: PENGABDIAN PRAJURIT KERATON YOGYAKARTA DALAM KARYA TARI

dan didasari oleh perjuangan dan semangat pengabdian yang dilakukan oleh Pak Dasiyo selama menjadi pasukan prajurit Kraton Yogyakarta.

Karya tari "Labuh Labet" adalah penciptaan karya dari masa akhir studi di Program Studi S-1 Tari, Fakultas Seni Pertunjukan, Institut Seni Indonesia Yogyakarta. Karya Tugas Akhir ini dapat juga dipandang sebagai ungkapan berbagai pengalaman selama berada di lingkungan dalam benteng Kraton dan selama menjalani studi di dunia seni pertunjukan. Evaluasi dari penikmat dan pengamat seni baik dari akademisi atau non akademisi sangat dibutuhkan untuk memacu semangat dan meningkatkan kemampuan berkarya selanjutnya.

Sebagai salah seorang generasi muda di lingkup dalam benteng kraton Yogyakarta, diharapkan untuk terus dapat melanjutkan tradisi leluhur dan tetap menjadikan bregada prajurit kraton sebagai kebanggaan budaya warga Yogyakarta. Selain itu, melalui keterlibatan dalam garapan ini, para penari diharapkan mendapatkan pengalaman dari apa yang diberikan, seperti dalam proses latihan yang sudah dilakukan bersama.

Naskah dalam bentuk tulisan karya tari ini dituangkan sebagai keterangan tertulis mengenai karya tari "Labuh Labet". Kami 
LABUH LABET: PENGABDIAN PRAJURIT

KERATON YOGYAKARTA DALAM KARYA TARI

mengucapkan terima kasih kepada Tuhan Yang Maha Esa dan semua pihak yang telah membantu menyelesaikan keseluruhan karya ini.

Belajar untuk menciptakan suatu karya tari adalah hal yang sangat berharga. Dari semula melihat berbagai macam pertunjukan, lalu mencoba menganalisis dan memahami apa sebenarnya yang ingin disampaikan dalam karya tari yang disajikan dan bagaimana proses yang dilakukan. Karena pada dasarnya, melakukan sebuah proses latihan dalam tari pada khususnya memiliki berbagai macam manfaat yang dapat diambil. Seperti setiap melakukan pemanasan atau melemaskan otototot badan sebelum memulai latihan, hal ini merupakan sebuah ajang untuk menempa dan melatih otot dan gerakan refleks tubuh yang akan dilakukan oleh seorang penari. Manfaat ini mungkin belum dapat langsung dirasakan oleh penari, namun jika metode ini dilakukan secara terus menerus maka hasil yang diperoleh juga akan memuaskan.

Karya tari "Labuh Labet" dapat diselesaikan melalui proses kreativitas yang cukup panjang. Banyak ilmu dan pengetahuan baru didapat berkaitan dengan penggarapan karya tari yang melibatkan banyak orang. Salah satunya, seorang koreografer harus mampu bersikap tegas dan mampu mengatur waktu dengan baik, sehingga proses dapat berjalan lancar sekaligus nyaman bagi semua yang
JOGED: Jurnal Seni Tari p-ISSN 1858-3989 | e-ISSN 2655-3171

terlibat. Keberhasilan sebuah karya sangat ditentukan salah satunya oleh keterlibatan penari. Para penari yang memiliki kemampuan dan ketrampilan yang baik, di satu sisi dapat membantu kelancaran proses, tetapi di sisi lain dapat menghambat karena, seringkali mereka terlalu sibuk membantu karya lain ataupun terlibat pada banyak pementasan yang membuat mereka sering izin dalam latihan. Untuk itu, seorang koreografer harus memiliki pertimbangan yang matang dalam memilih penari, demikian juga dalam menetapkan elemen lain yang digunakan. Karena semua elemen yang mendukung dalam suatu karya tari memiliki kesinambungan untuk dapat bekerja sama sesuai dengan peran serta fungsi dari masing-masing individu.

\section{DAFTAR SUMBER ACUAN}

\section{A. Sumber Tertulis}

Admadipurwa, Purwadmadi. 2007. Joget mBagong di Sebalik Tarian Bagong

Kussudiardja. Yogyakarta: Yayasan Bagong Kussudiardja.

Hadi, Y. Sumandiyo. 2003. Aspek-Aspek Dasar Karya Tari Kelompok. Yogyakarta: Manthili.

Hadi, Y. Sumandiyo. 2007. Kajian Tari Teks dan Konteks. Yogyakarta: Pustaka Book Publisher/ 
JOGED: Jurnal Seni Tari

p-ISSN 1858-3989 | e-ISSN 2655-3171

Hadi, Y. Sumandiyo. 2016. Koreografi:

Bentuk Teknik Isi. Yogyakarta: Cipta Media.

Humphrey, Doris. 1983. The Art of

Making Dance. Diterjemahkan oleh

Murgiyanto,

Sal. 1983. Seni Menata Tari. Jakarta: Aquarista Offset.

Mangunsuwito, S.A. 2010. Kamus

Lengkap Bahasa Jawa. Bandung: C.V. Yrama

Widya.

Martono, Hendro. 2008. Sekelumit

Ruang Pentas Modern dan Tradisi.

Yogyakarta: Cipta Media.

Martono, Hendro. 2010. Mengenal

Tata Cahaya Seni Pertunjukan.

Yogyakarta: Cipta Media.

Martono, Hendro. 2012. Ruang

Pertunjukan dan Ruang Berkesenian,

Yogyakarta: Cipta Media.

Meri, La. 1975. Dances Composition, The Basic Elements, diterjemahkan Soedarsono, 1986, Elemen-elemen Dasar

Komposisi Tari. Yogyakarta: Lalaligo.

Musman, Asti. 2015. Lurik (Pesona, Ragam, dan Filosofi). Yogyakarta: Andi Offset.

Purwadi. 2007. Sejarah Raja-Raja Jawa. Yogyakarta: Media Abadi.
LABUH LABET: PENGABDIAN PRAJURIT KERATON YOGYAKARTA DALAM KARYA TARI

Smith, Jacqueline. 1976. Dance Composition, A Practical Guide For Teachers, diterjemahkan Ben Suharto, 1985 Komposisi Tari Sebuah Petunjuk Praktis Bagi Guru. Yogyakarta: IKALASTI.

Soedarsono, R.M. 2002. Seni

Pertunjukan Indonesia di Era Globalisasi.Direktorat Jendral Pendidikan Tinggi Departemen Pendidikan dan Kebudayaan. Jakarta

Soelarto, B. 1993. Garebeg di Kesultanan Yogyakarta. Yogyakarta: Kanisius.

Suwito, Yuwono Sri. 2009. Prajurit Kraton Yogyakarta Filosofi dan Nilai Budaya yang Terkandung Di Dalamnya. Dinas Pariwisata dan Kebudayaan Kota Yogyakarta, Yogyakarta.

B. Sumber Webtografi:

https://blogsederhanaala47.wordpress.com /2012/08/30/bahasa-jawa-ngoko-inggil/.

Diunggah ke internet pada tanggal 30 Agustus 2012 oleh Kurniawan Budi, diunduh pada tanggal 23 Februari 2017.

https://lembahsungaibedog.blogspot.co.id/ 2014/01/kesatuan-prajuritkeratonkasultanan.html. Diunggah ke internet pada tanggal 18 Januari 2014 oleh Lembah Bedog Agro, diunduh pada tanggal 1 Maret 2017.

http://www.cendananews.com/2015/05/menge nal-lebih-dekat-prajurit-prajurit.html.

Diunggah ke internet pada tanggal $26 \mathrm{Mei}$ 2015 oleh Mohammad Natsir, diunduh pada tanggal 7 Maret 2017. 


\section{Videografi}

Video dokumentasi pelaksaan ujian kelas Koreografi Mandiri pada tanggal 21 Desember 2016 yang diselenggarakan di proscenium stage Jurusan Tari, Fakultas Seni Pertunjukan, Institut Seni Indonesia Yogyakarta, koleksi Putra Jalu Pamungkas.

\section{Sumber Lisan}

Arsa (24 tahun), prajurit Ungel-Ungelan Bregada Jogokaryo.

Dasiyo (77 Tahun), (KRT

Dwijosudasiyo), Panji Bregada Wirabraja.

Enggar Pikantoyo (Kusumanegara) (46 tahun), staf Tepas Kaprajuritan.

Endang (48 tahun), guide di kraton Yogyakarta.

Prof Dr. Y. Sumandyo Hadi, S.S.T .,SU, (68 tahun), guru besar ISI Yogyakarta 